\title{
Sacral neuromodulation for treatment of overactive bladder: a review
}

\author{
Neuromodulação sacral no tratamento da bexiga hiperativa: revisão
}

\author{
Cristiano Mendes Gomes, João Victor Teixeira Henriques, \\ Rachel Mazoni Costa, Flavio Eduardo Trigo-Rocha
}

Gomes CM, Henriques JVT, Costa RM, Trigo-Rocha FE. Sacral neuromodulation for treatment of overactive bladder: a review / Neuromodulação sacral no tratamento da bexiga hiperativa: revisão. Rev Med (São Paulo). 2018 May-June;97(3):340-7.

\begin{abstract}
Sacral neuromodulation (SNM) therapy is an established third line therapeutic option for the treatment of urgency urinary incontinence, urgency-frequency and chronic non-obstructive urinary retention. The continuous stimulation of the sacral root $\mathrm{S} 3$ with an electrode connected to an implanted pulse generator (IPG) may influence detrusor and sphincter activity and improve lower urinary tract symptoms. The mechanism of action is not completely understood and seems to be based on the modulation of spinal cord reflexes and brain centers involved in lower urinary tract function. It is implanted with a minimally invasive technique that can be performed under local anesthesia and includes a test phase that precedes the definitive implantation of the pulse generator. When compared to the standard pharmacological therapy, neuromodulation promoted better results both in the partial improvement of overactive bladder $(\mathrm{OAB})$ symptoms and total continence. Moreover, sexual function, quality of life and depressive symptoms may also improve in patients with OAB that undergo SNM. However, SNM is associated with significant rates of adverse events and need for surgical revisions, requiring continuous medical attention.
\end{abstract}

Keywords: Electric stimulation therapy/adverse effects; Urinary bladder, overactive; Urinary incontinence; Urinary tract/ physiopathology.
RESUMO: A neuromodulação sacral (NMS) é uma opção bem estabelecida de tratamento de terceira linha da bexiga hiperativa, incluindo as indicações de urgência-frequência, incontinência urinária de urgência e também a retenção urinária crônica não obstrutiva. A estimulação contínua da raiz sacral S3, através de um eletrodo conectado a um gerador de pulsos implantado, pode influenciar a função do detrusor e do esfíncter uretral e melhorar os sintomas do trato urinário inferior. O mecanismo de ação não é totalmente conhecido e parece basear-se na modulação dos reflexos medulares e dos centros cerebrais envolvidos no controle da função do trato urinário inferior. O eletrodo sacral é implantado com técnica minimamente invasiva, que pode ser realizada com anestesia local, e inclui uma fase de teste que precede o implante definitivo do gerador de pulsos. Em comparação com o tratamento farmacológico padrão da bexiga hiperativa, a NMS promove melhores resultados na melhora dos sintomas e nas taxas de cura. Além disso, a função sexual, a qualidade de vida e os sintomas depressivos também podem melhorar nos pacientes com bexiga hiperativa que são submetidos à NMS. No entanto, a NMS acompanha-se de significativas taxas de eventos adversos e de necessidade de revisões cirúrgicas, requerendo acompanhamento clínico periódico.

Descritores: Terpaia por estimulação elétrica/efeitos adversos; Bexiga urinária hiperativa; Incontinência urinária; Sistema urinário/fisiopatologia.

Divisao de Urologia, Hospital das Clinicas HCFMUSP, Faculdade de Medicina, Universidade de Sao Paulo, Sao Paulo, SP, BR. (Division of Urology, University of São Paulo School of Medicine, São Paulo, SP, BR.)

ORCID: Gomes CM - https://orcid.org/0000-0002-8486-4003 ; Henriques JCT - https://orcid.org/0000-0002-5552-4982; Costa RM https://orcid.org/0000-0002-8462-806X; Trigo-Rocha FE - https://orcid.org/0000-0003-4362-1715.

Corresponding author: Dr. Cristiano Mendes Gomes. Hospital das Clínicas da Faculdade de Medicina da USP. Divisão de Clinica Urológica. Avenida Dr. Enéas de Carvalho Aguiar, 255 - Sala 710F - 7º. Andar. São Paulo, SP, Brasil. CEP: 05403-000. E-mail: crismgomes@uol.com.br. 


\section{INTRODUCTION}

Sacral neuromodulation (SNM) was developed in the early 1980s by Tanagho and Schmidt ${ }^{1,2}$. They showed that continuous stimulation of the sacral root S3 with an electrode connected to an implanted pulse generator (IPG) could influence detrusor and sphincter activity and improve lower urinary tract symptoms ${ }^{3}$. InterStim ${ }^{\circledR}$ Therapy (Medtronic, Minneapolis, MN, USA) is licensed by the US Food and Drug Administration (FDA) for the treatment of urinary urge incontinence (UI) since 1997 and for urgency-frequency (UF) and chronic non-obstructive urinary retention (UR) since 1999. SNM may also be used for other forms of bladder dysfunction including disorders such as chronic pelvic pain and interstitial cystitis as well as for faecal incontinence ${ }^{4-7}$.

The main indication for SNM is as a third line therapy for overactive bladder (OAB). The International Continence Society (ICS) defines OAB as a syndrome composed of urgency, with or without urge incontinence, usually with frequency and nocturia ${ }^{8}$. The first line therapy of OAB includes behavioral treatments (BT) which are a group of therapies that aim to improve OAB symptoms by modifying patient behavior or his/her environment (9). Most BT programs include multiple components and are individualized to the needs of the patient and his/her particular living situation. There are two main approaches to BT for OAB. One targets the modification of bladder function by changing voiding habits, such as with bladder training and delayed voiding. The other approach focuses on the bladder outlet and includes pelvic floor muscle training to enhance strength and control and techniques for urge suppression. The second-line treatment of OAB consists of pharmacotherapy with antimuscarinics or a beta-3 agonist ${ }^{9}$. Other agents may also be used.

When patients are refractory to conservative treatments (BT and pharmacotherapy) minimally invasive therapies such as SNM, injection of botulinum toxin in the detrusor or percutaneous tibial nerve stimulation may be indicated ${ }^{9}$. In this manuscript, we will discuss the use of SNM as a third line therapy for OAB.

\section{DISCUSSION}

\section{Mechanism of Action and Technique}

The mechanism of action of SNM is not fully known. The therapeutic effects of SNM may come from the electrical stimulation on afferent and efferent nerve fibers connecting the pelvic viscera and pelvic floor muscles and the spinal interneurons to the central nervous system. There is no definitive evidence of permanent remodeling, reinnervation or alteration of pathways in the central or peripheral nervous systems in humans following SNM therapy. It seems to predominantly affect sacral afferents and modulate spinal cord reflexes and brain centers that are involved in lower urinary tract function ${ }^{10-12}$.

The current SNM technique is minimally invasive and can be performed under local anesthesia. Briefly, it is performed with the patient in prone position using local anesthesia with or without mild sedation or even general anesthesia. Usually, a local anesthetic is applied around the area where the definitive lead will be implanted (posterior to the sacrum). With the patient awake it is possible to evaluate the sensory responses to electrical stimulation. The needle is inserted through the third sacral foramina, (S3). Fluoroscopy is used to monitor the position of the needle and the motor and sensory responses to electrical stimulation are tested to ascertain the adequate positioning. Once this is secured, a guide wire is inserted through the needle and serve as a guide for the dilator. Fluoroscopy is used to guide the appropriate positioning of the definitive quadripolar lead (Figure 1). After lead placement. the patient undergoes a test phase which may last up to 20 days, to determine whether SNM has provided a relevant benefit. It is usually accepted that improvements of more than 50\% in symptoms are considered a successful outcome. If the results of the test phase are positive, the IPG is implanted in the upper buttocks ${ }^{13-15}$.

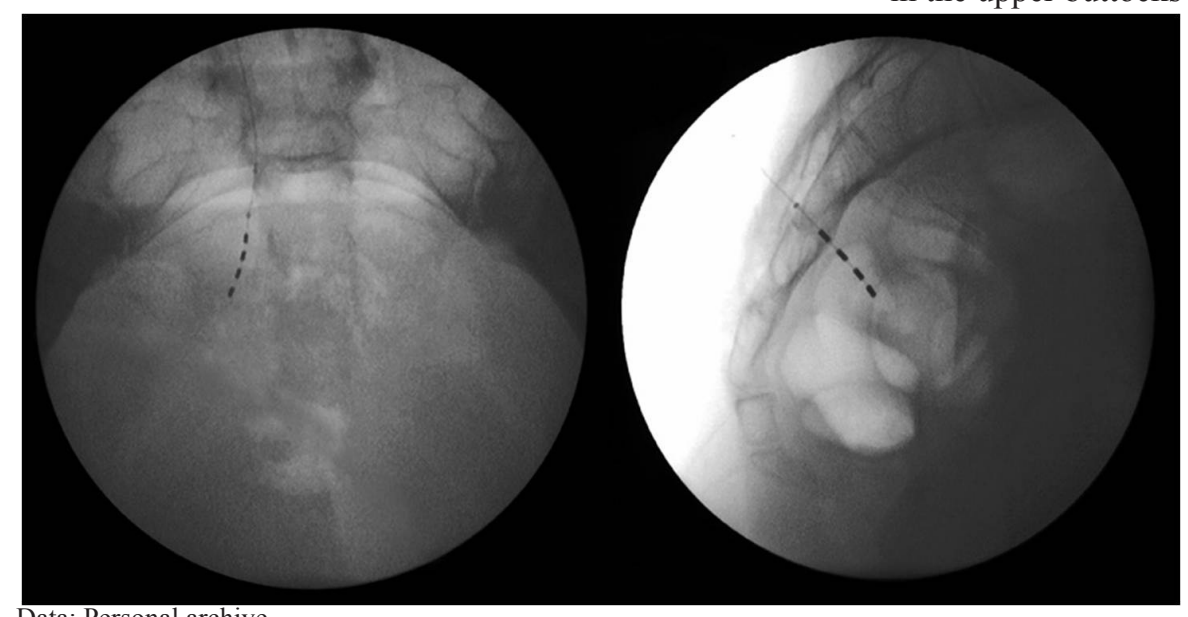

Figure 1 - Radiographic view of the correct position of the electrode. Anterior view (left); lateral view (right) 
The test phase of SNM may also be performed by peripheral nerve evaluation (PNE), but most physicians prefer the staged implantation of a tined-lead for the first stage because the PNE technique is associated with high false negative rates ${ }^{16-18}$. Once implanted and in continuous use, the battery of the IPG has an average durability of 3 to 6 years, depending on the parameters of stimulation that are used.

\section{SNM vs no therapy}

Outcomes of sacral nerve stimulation (SNS) for UI and UF are based principally on a limited number of studies that randomized patients to active or delayed therapy as well as various prospective and retrospective case series. Schmidt et al. ${ }^{19}$ reported on SNS therapy in 76 patients with refractory UI from 16 centers worldwide randomized to active or delayed therapy (control group) during the study period of 6 months ${ }^{19}$. The episodes of incontinence and the number of pads used were significantly reduced in the stimulation group when compared to the control group. Sixteen (47\%) of the 34 patients, receiving active SNS therapy, were reported as completely dry and an additional 10 (29\%) described more than 50\% reduction in incontinence episodes. Patients returned to baseline levels of incontinence when stimulation was turned off. Hassouna et al. ${ }^{20}$ noted the outcomes of SNS for refractory UF in 51 patients randomized from 12 centers during an initial 6-month period that was extended to 2 years. The data report at 6 months in the active SNS group showed decrease in the number of daily voids $(16.9 \pm 9.7$ to $9.3 \pm$ $5.1)$, increase in the volume voided $(118 \pm 74 \mathrm{~mL}$ to 226 $\pm 124 \mathrm{~mL}$ ), lower degree of urgency (rank score of $2.2 \pm$ 0.6 to $1.6 \pm 0.9$ ), and improvement on the SF-36 quality of life (QOL) measures. At 6 months after implantation, stimulators in the active group were switched off and urinary complaints returned to baseline values. After reactivation of SNS, sustained efficacy was documented at 12 and 24 months $^{20}$.

A review on the Cochrane database, from $2009^{21}$, investigated the evidence of the effects of SNM in the management of UI, UF and UR. Eight RCTs were included in the analysis. At 6 months follow-up, SNM was superior to no treatment for all indications with highly significant improvements in all outcomes measured (leakage episodes, number of voids, rating of urgency, pad usage, bladder capacity). The authors concluded that SNM can deliver benefit to a selected group of patients.

\section{SNM vs medical therapy}

The InSite trial is a prospective, multi-center, randomized clinical trial comparing SNM to standard medical therapy (SMT). It is based on treating patients with refractory mild to moderate symptoms of OAB, within a six-month follow-up period ${ }^{18}$. The second phase is a prospective long-term evaluation of the efficacy and safety of SNM, to assess the cumulative five-year rate of adverse events (AEs) including need for surgery, rates of infection and lead migration as well as therapeutic success and QOL. Investigators have published results for one $\mathrm{e}^{22}$ and three years ${ }^{15}$ of follow-up. The OAB therapeutic success, which was determined by voiding diaries at the 6-month follow-up visit, was defined for patients with UI and UF as a $\geq 50 \%$ improvement in average leaks/day or voids/day from baseline or a return to normal voiding frequency $(<8$ voids/day), respectively. The impact on sexual function and depressive symptoms were additional objectives. Of 147 randomized individuals, 93\% were women and mean age was 58 years. Subjects randomized to SNM underwent a staged procedure using the InterStim during a 14-day test stimulation period. If a successful test stimulation occurred, the neurostimulator was implanted. Of the 70 subjects randomized to SNM, 59 underwent test stimulation and $51 / 59(86 \%)$ received a full system implant. The OAB therapeutic success, on the primary analysis, was greater in the SNM group (61\%), when compared to the SMT group $(42 \% ; \mathrm{P}=0.02)$.

In the final analysis, the therapy success rate was $76 \%$ for SNM and $49 \%$ for SMT $(\mathrm{P}=0.002)$. Complete continence was higher in the SNM group (39\% vs $21 \%$ in the SMT group; $\mathrm{P}=0.06$ ) which also showed significant improvements in QOL versus the SMT group (all $\mathrm{P}<$ $0.001)$. The women treated with SNM had a greater improvement in sexual function and depression compared to SMT. The device-related adverse event rate was $30.5 \%$ and the medication-related adverse event rate was $27.3 \%$, none of which were serious. The most common devicerelated adverse events in SNM subjects were undesirable change in stimulation in $10.2 \%(6 / 59)$, implant site pain $8.5 \%(5 / 59)$, lead migration/ dislodgment 3.4\% (2/59), and implant site infection 3.4\% (2/59). For the 51 SNM subjects with full system implant, the surgical intervention rate after 6 months was 3.9\% (2/51). The most usual OAB medication-related events were constipation in $9.1 \%$, drug toxicity in $6.5 \%$ and dry mouth in $5.2 \%$.

\section{SNM vs botulinum toxin-A (BTX-A)}

Botulinum toxin-A (BTX-A) is approved for use as a third-line therapy in patients with refractory idiopathic OAB. The efficacy rates reported for BTX-A and SNM in patients with refractory $\mathrm{OAB}$ appear to be comparable, but there is no RCT to compare the efficacy and safety of both methods. SNM is more invasive but offers long-term efficacy whereas the injection of BTX-A is less invasive but needs to be repeated on a less than a year basis in order to provide sustained efficacy. Each treatment modality has its own range of possible AEs. 
The ROSETTA - Refractory Overactive Bladder: Sacral Neuromodulation vs Botulinum Toxin Assessment - trial is a randomized controlled trial designed to compare treatment with $200 \mathrm{U}$ of onabotulinumtoxinA (the only BTX-A presentation approved for use in the bladder at the time of the study) injected in the detrusor versus $\mathrm{SNM}$ in female patients with refractory $\mathrm{OAB}^{23}$. A total of 369 patients were treated after being randomized for both groups. The mean age of the patients was 63 years and more than $80 \%$ considered themselves as severely or very severely incontinent. In the SNM group, subjects underwent a two-stage procedure. The rate of clinical response, measured at 1 month in the injection group and during the test phase in the neuromodulation group, was similar in the injection and SNM groups ( $83 \%$ vs $84 \%)$.

The onabotulinumtoxinA group reported significantly greater reduction in daily urgency urinary incontinence episodes compared to the neuromodulation group, concerning both the intention to treat and clinical responder. In the intention-to-treat analysis at 6 months, the change in the mean number of daily incontinence episodes from baseline was -3.9 in the injection group and -3.3 episodes/day in the SNM group; $\mathrm{P}=0.01$ ). The injection group patients had greater complete symptom resolution at 6 months than the SNM group $(20 \%$ vs $4 \%$; $><.0001)$. Both groups had a better performance in the $\mathrm{OAB}$ symptom questionnaire. Treatment satisfaction rate was higher in the injection group than in the neuromodulation group $(\mathrm{P}=0.01)$.

Adverse Events: At 6 months, the rate of urinary tract infection was higher in the injection group than in the neuromodulation group $(35 \%$ vs $11 \% ; \mathrm{P}<.0001)$. Intermittent catheterization was required by $8 \%$ of patients at 1 month, $4 \%$ at 3 months, and $2 \%$ at 6 months, in the injection group. In the neuromodulation group, $3 \%$ of patients required surgical revision or removal. In this study a $200 \mathrm{U}$ dose of onabotulinum toxin A was used, despite the fact that the FDA-approved dose is $100 \mathrm{U}$. Longer term follow-up underway may improve our understanding of how these treatment modalities differ in the management of refractory OAB.

In another study, Smits et al. ${ }^{24}$ evaluated the use of SNM in patients who discontinued BTX-A treatment. They reported on a group of 14 patients who had discontinued BTX-A treatment due to lack of efficacy (85\%) or the desire for a more permanent treatment (15\%). After one year of implantation, 11 of 14 patients (79\%) were satisfied with treatment ${ }^{24}$.

\section{SNM long term data}

The long-term results of SNM have been approached by several case studies. It is relevant to point out that most studies reporting on long term data refer to older SNM technology and it is possible that, in the face of the new techniques available, efficacy and complication rates will improve. De Groen et al. ${ }^{25}$ evaluated the long-term results of SNM in patients with refractory UI. A total of 60 subjects were prospectively evaluated at regular intervals for at least 5 years after implantation. Approximately $15 \%$ of patients achieved complete continence. After a 10-year follow-up, $25(61 \%)$ of 41 patients were still on active SNM.

The success rates after 10 years did not show much difference from the 5-year results suggesting that a deterioration of the results is observed during the first 5 years, which stabilized thereafter. Fifty-seven AEs occurred in $32(53 \%)$ patients, hardware failure and pain or discomfort at various sites were the responsibles for the greater number of them. Twenty-three reoperations, including 2 explantations, were done in 15 patients (25\%).

At 5 years post-surgery, greater than $50 \%$ improvement was achieved by $68 \%$ of those with UI and $56 \%$ of those with UF, according to the evaluation of the same groups of $\mathrm{OAB}$ patients by different long-term studies. A number of retrospective studies stated on the long term efficacy of SNM for different urological conditions. A total of 217 patients, with a follow-up of 47 months, were evaluated by Peeters et al. ${ }^{26}$ The rates of success and cure for UI were $70 \%$ and $20 \%$, and for UF were $68 \%$ and $33 \%$, respectively. The mean time to failure after implantation, on the cases of unsuccessful outcome, was 24.6 months. Most of the re-interventions (47\%) were performed within the first two years of follow up, At least one re-intervention was needed in $88(41 \%)$ patients

The authors of the InSite study, previously quoted, evaluated the success rates of SNM at $12^{22}$ and 36 months ${ }^{15}$. Of 272 patients with the IPG, $91 \%$ were female with a mean age of 57 years. The final data analysis showed a sustainable response of SNM through 36 months, with a mean decrement of 2.2 leaks/day after 12 months and 2.3 leaks/ day after 36 months $(P<0.0001)$. Subjects demonstrated significant augmentation from baseline in all measures of ICIQ-OABqol and 80\% reported improved changes in their urinary symptom interference at 12 and 36 months.

Adverse effects related to the device occurred in $16 \%$ of subjects during test stimulation, $30 \%$ of subjects 12 months post-implant and $47 \%$ after 36 months. Undesirable change in stimulation (18\%), implant site pain (13\%), and therapeutic product ineffective $(6 \%)$ were the most frequent $\mathrm{AE}$ types reported. Lead migrations were reported in $4 \%$ of subjects, most of them occurring between 12 and 24 months post-implant. implant site infections were reported in $4 \%$ of individuals, half reported in the first 3 months post-implant. Surgical interventions related to the neurostimulator, lead, or chronic extension ocurred in $32 \%$ 
of subjects after implant. The replacement and revision rates of the device were $20 \%$ and $4 \%$, respectively. Surgical interventions to perform battery replacement occurred in $11 \%$ of subjects, and $93 \%$ of these neurostimulators were assessed to be within the expected longevity ranges based on the set parameters of the device. The top reason for permanent explant, which occurred in $13 \%$ of subjects, was due to an $\mathrm{AE}(8 \%)$. Other reasons were lack and/or loss of efficacy in $3 \%$, subjects need for magnetic resonance imaging and "other".

Although the long-term clinical effectiveness of SNM has been confirmed by many studies, its repercussion on patient satisfaction and enhancement of QOL has not been clearly stablished. One can not neglect that a significant proportion of patients experience technical problems and adverse effects requiring constant medical attention and surgical revisions. Leong et al. ${ }^{27}$ examined the patients rates of long-term satisfaction with an implanted SNM for various medical indications such as overactive bladder syndrome, non-obstructive UR, combined OAB and UR, and pelvic pain. Overall, 275 patients answered a postal questionnaire regarding satisfaction and experiences with the method, such as side effects, complications, burden, impact on sexuality and defecation changes. The rate of symptom improvement was $75 \%$ (207 patients) with a median post-implantation evaluation period of 77 months (range 12 to 214 ). The patient satisfaction rate was $90 \%$ and significantly related to the sensed clinical effect and $85 \%$ of all explanted cases (13 patients) were considered as failures. Satisfaction with the treatment was not associated with patient age, gender, duration of therapy or type of complaint for which SNM was offered, but was lower in patients with more than 1 pelvic floor comorbidity. The patient's attitude towards yearly follow-up and the skill to use the programmer was positively related to the satisfaction rate. Forty percent of subjects reported some limitations or preoccupation with SNM such as exclusion from MRI and passing through metal detectors. The majority of patients perceived regular pain (56\%) and discomfort (40\%).

Table 1 shows the results for some of the most important studies on SNM for the treatment of refractory OAB.

\section{Predictors of outcomes}

Several research groups have investigated a number of possible predictors of success for SNM in $\mathrm{OAB}$ patients, including age, severity of incontinence, obesity, prior medication use, previous spinal surgery, urodynamic findings and other. Davis et al showed similar success rates at the trial phase for patients who received SNS as a treatment due to lack of medication efficacy versus intolerable medication side effects $(70 \%$ and $71 \%$ respectively $)^{28}$.

Yazdany et al. ${ }^{29}$ also reported the success in the test phase in a group of patients with severe incontinence (mean 10.4 episodes/day); the authors observed that patients with $>10$ incontinence episodes per day had greater propensity to have a successful stage I trial in comparison to those with less than 5 episodes/day. Levin et al. ${ }^{30}$ reported on the influence of obesity on stage I success rates. Eighty (53.7\%), of 149 patients, were obese (BMI mean 37.3) and 69 (46.3\%) were non-obese (BMI mean 25.6). The success rates are comparable among the groups of obese $(78 \%)$ and non-obese $(83 \%)$ patients. The overall rate of success is $81 \%{ }^{30}$.

Peters et al. ${ }^{31}$ analyzed medical records of adults enrolled in a prospective observational study in order to evaluate the impact of age on the outcomes of SNM. The rate of IPG implant (89-90\%) and explant (9.3-13\%) did not vary between different age groups $(<40$ years, $40-64$ and $>/=65$ ) but there was a tendency for higher complication rates in younger patients ( $23 \%$ vs. $15 \%$ vs. $8.5 \%$, respectively; $\mathrm{P}=0.08$ ). The same group evaluated possible predictors of reoperation after SNM in a single center retrospective study ${ }^{32}$. The data of 407 patients were reviewed, at least one reoperation was performed in 134 (33\%) subjects, over a median follow-up of 28.9 months, including 78/407 (19\%) revisions and 56/407 (14\%) explantations. The lack and/or loss of efficacy was the most common reason for reoperation $(65 \%)$. On multivariate analysis, only longer follow-up ( $\mathrm{P}=0.0011$; OR 1.048; CI $1.019,1.078)$ and having a complication $(\mathrm{P}<0.0001$; OR 23.2; CI 11.47, 46.75) were significant predictors of reoperations.

Angioli et al. ${ }^{33}$ revealed their results of SNM in patients older than 65 years (mean patient age 76 years). At 12 months post-implant, $83.3 \%$ of patients reported improvement and $55.5 \%$ of patients reported complete success with ending of UUI episodes. On the same report, the mean episodes of UUI had a critical reduction from 6.3/ day to $0.5 /$ day. Incontinence episodes, frequency, nocturia, and number of pads used daily also significantly decreased. All subscales of the OAB-q were significantly improved.

The role of urodynamics as an outcome predictor for SNM is not clear ${ }^{34}$. There was no relationship between the presence or absence of DO and the likelihood for test stimulation success, when evaluating 104 patients with refractory $\mathrm{UI}^{35}$. Drossaerts et al. ${ }^{36}$, while exploring the predictive role of conventional and ambulatory urodynamics for SNM outcome, found similar success rates for SNM in patients with storage dysfunction according to either conventional-UDS or ambulatory-UDS. 
Gomes CM, et al. Sacral neuromodulation for treatment of overactive bladder: a review.

Table 1. Results from selected studies on SNM for refractory overactive bladder

\begin{tabular}{|c|c|c|c|c|c|}
\hline Author & $\mathbf{N}$ & Study design & $\begin{array}{l}\text { Follow } \\
\text { up }\end{array}$ & Results & Adverse events \\
\hline $\begin{array}{l}\text { Schmidt et } \\
\text { al. }{ }^{19}\end{array}$ & $\begin{array}{l}76 \text { ( } 34 \text { SNM Vs. } \\
42 \text { crontrol group) }\end{array}$ & $\begin{array}{l}\text { randomized, } \\
\text { multi-center }\end{array}$ & $6 \mathrm{mths}$ & $\begin{array}{l}16(47 \%) \text { completely dry; } 10 \\
(29 \%)>50 \% \text { reduction in } \\
\text { incontinence episodes }\end{array}$ & $\begin{array}{l}15.9 \% \text { IPG site pain, } 19.1 \% \\
\text { implant site pain, } 7 \% \text { lead } \\
\text { migration, } 32.5 \% \text { surgical review }\end{array}$ \\
\hline $\begin{array}{l}\text { Hassouna et } \\
\text { al. }{ }^{20}\end{array}$ & $\begin{array}{l}51 \mathrm{SNM}(90 \% \\
\text { women })\end{array}$ & $\begin{array}{l}\text { randomized, } \\
\text { multi-center }\end{array}$ & $6 \mathrm{mths}$ & $\begin{array}{l}\text { Daily voids from } 16.9 \text { to } 9.3 ; \\
\text { Volume voided from } 118 \mathrm{ml} \text { to } \\
226 \mathrm{ml} \text {; lower degree of urgency }\end{array}$ & $\begin{array}{l}\text { There were no reports of serious } \\
\text { adverse events or permanent } \\
\text { injury associated with the } \\
\text { devices }\end{array}$ \\
\hline $\begin{array}{l}\text { Cochrane } \\
\text { review. }{ }^{21}\end{array}$ & 500 & $\begin{array}{l}\text { Systematic } \\
\text { review of } 8 \\
\text { randomized } \\
\text { controlled } \\
\text { trials }\end{array}$ & $6 \mathrm{mths}$ & $\begin{array}{l}\text { SNM promoted significant } \\
\text { improvements compared to } \\
\text { no treatment in all outcomes } \\
\text { (leakage episodes, number of } \\
\text { voids, rating of urgency, pad } \\
\text { usage, bladder capacity) }\end{array}$ & $\begin{array}{l}15.3 \% \text { pain at implant site, } 9 \% \\
\text { new pain, } 8.4 \% \text { lead migration, } \\
6.1 \% \text { infection, } 5.5 \% \text { transient } \\
\text { sensation of electrical shock, } \\
5.4 \% \text { pain at lead site, } 33.3 \% \\
\text { surgical review }\end{array}$ \\
\hline $\begin{array}{l}\text { Siegel et al. } \\
(\text { InSite trial })^{18}\end{array}$ & $\begin{array}{l}70 \text { to SNM; } 59 \\
\text { first stage; } 51 \\
(86 \%) \text { implanted; } \\
77 \\
\text { pharmacotherapy; } \\
93 \% \text { women }\end{array}$ & $\begin{array}{l}\text { prospective, } \\
\text { multi-center, } \\
\text { randomized }\end{array}$ & $6 \mathrm{mths}$ & $\begin{array}{l}\geq 50 \% \text { improvement in } \\
76 \% \text { for SNM and } 49 \% \text { for } \\
\text { pharmacotherapy }(p=0.002) \\
\text { Complete continence } 39 \% \text { SNM } \\
\text { vs } 21 \%\end{array}$ & $\begin{array}{l}30.5 \% \text { had device-related } \\
\text { adverse events and } 27.3 \% \text { had } \\
\text { medication-related } \mathrm{AE}\end{array}$ \\
\hline $\begin{array}{l}\text { Noblett (inSite } \\
\text { trial) }\end{array}$ & $\begin{array}{l}272 \text { subjects } \\
\text { received SNM } \\
(91 \% \text { women })\end{array}$ & $\begin{array}{l}\text { prospective, } \\
\text { multi-center }\end{array}$ & $\begin{array}{l}12 \\
\text { mths }\end{array}$ & $\begin{array}{l}\text { decreased } 2.2 \text { leaks/day }(\mathrm{P}< \\
0.0001) \text {, UF subjects had a } \\
\text { mean reduction of } 5.1 \text { voids/ } \\
\text { day in } 12 \mathrm{mths} ; 80 \% \text { reported } \\
\text { improved Qol }\end{array}$ & $\begin{array}{l}16 \%(56 / 340) \text { had AE related } \\
\text { to the device during test phase; } \\
30 \%(82 / 272) \text { post implant }\end{array}$ \\
\hline $\begin{array}{l}\text { Siegel et al. } \\
\text { (inSite trial) }^{15}\end{array}$ & $\begin{array}{l}272 \text { subjects } \\
\text { received SNM } \\
(91 \% \text { women })\end{array}$ & $\begin{array}{l}\text { prospective, } \\
\text { multi-center }\end{array}$ & $\begin{array}{l}36 \\
\text { mths }\end{array}$ & $\begin{array}{l}\text { decreased } 2.3 \text { leaks/day }(\mathrm{P}< \\
0.0001) \text { and UF subjects had a } \\
\text { mean reduction of } 5.3 \text { voids/ } \\
\text { day }(\mathrm{P}<0.0001) \text { in } 36 \mathrm{mths} ; 80 \% \\
\text { reported improved Qol }\end{array}$ & $\begin{array}{l}47 \%(127 / 272) \text { had } \mathrm{AE} \text { related to } \\
\text { the device after } 36 \mathrm{mths}\end{array}$ \\
\hline $\begin{array}{l}\text { Amundsen et } \\
\text { al. (Rosetta } \\
\text { trial) })^{23}\end{array}$ & $\begin{array}{l}369 \text { randomized } \\
\text { for SNM or } \\
\text { BTX-A }\end{array}$ & $\begin{array}{l}\text { randomized } \\
\text { controlled, } \\
\text { multi-center }\end{array}$ & $6 \mathrm{mths}$ & $\begin{array}{l}\text { complete symptom resolution } \\
\text { in } 20 \% \text { BTX-A vs } 4 \% \text { SNM. } \\
\text { Reduction of at least } 75 \% \\
\text { in episodes per day in } 46 \% \\
\text { in Btx-A vs } 26 \% \text { in } \mathrm{SNM} \\
(\mathrm{P}=0.002)\end{array}$ & $\begin{array}{l}\text { UTI } 35 \% \text { in BTX-A group vs } \\
11 \% \text { in } \mathrm{SNM} \text {; CIC in } 2 \% \text { in } \\
\text { BTX-A }(\mathrm{P}<0.001) ; 3 \% \text { of SNM } \\
\text { required surgical revision or } \\
\text { removal }\end{array}$ \\
\hline $\begin{array}{l}\text { De Groen et } \\
\text { al. }{ }^{25}\end{array}$ & 60 women & prospective & $5 \mathrm{yrs}$ & $\begin{array}{l}\text { Success rate decreased from } \\
52 \text { patients }(87 \%) \text { at } 1 \text { month } \\
\text { to } 37(62 \%) \text { at } 5 \text { years. } 15 \% \\
\text { with complete continence; } \\
\text { improvement in } 68 \% \text { with UI } \\
\text { and } 56 \% \text { with UF }\end{array}$ & $\begin{array}{l}57 \mathrm{AE} \text { in } 32(53 \%) \text { patients } \\
\text { - hardware failure and pain or } \\
\text { discomfort } \\
\text { - reoperations }(15-25 \%) \\
\text { - explantations }(2.5 \%)\end{array}$ \\
\hline Peeters et al. ${ }^{26}$ & 217patients & retrospective & $47 \mathrm{mths}$ & $\begin{array}{l}70 \% \text { success rate and } 20 \% \text { cured } \\
\text { for UI; } 68 \% \text { success rate and } \\
33 \% \text { cured for UF }\end{array}$ & $\begin{array}{l}\text { at least one reintervention was } \\
\text { needed in } 88(41 \%) \text { patients }\end{array}$ \\
\hline
\end{tabular}

Legends. SNM: Sacral neuromodulation; AE: adverse events; QoL: quality of life; BTX-A: botulinum toxin A (OnabotulinumtoxinA); CIC: clean intermittent catheterization; UI: OAB with urinary incontinence; UF: OAB without urinary incontinence; IPG: Implantable pulse generator. 


\section{Magnetic Resonance Imaging (MRI) recommendations}

There is limited evidence that MRI may be performed with no harm to the patient based on few case reports or small case series that have reported on the use of MRI under very specific conditions ${ }^{37-39}$. Thus, possessing an implantable electrical stimulation device is considered a contraindication to undergo an MRI.

\section{Pregnancy}

Electrical stimulation has the potential to induce teratogenicity or abortion and SNM has been considered contraindicated in pregnant women. It is advisable for the pregnant woman to turn off their devices until the child is born ${ }^{39}$.

\section{CONCLUSIONS}

SNM is an effective therapy for selected individuals with UF/UI refractory to conservative therapy. Patients should be counseled regarding the potential for significant adverse events and rates of surgical revisions. Maintenance of favorable therapeutic effect requires patient's commitment to comply with long term monitoring and adjustment of the implant. Preoperative predictors of optimal patient response to this invasive therapy remain unclear and the test phase is needed in almost all patients to ascertain the indication of the definitive implantation. The role of SNM in combination with other therapies is undefined. Continuous improvements of SNM technology are expected to minimize the rates of adverse events and surgical revision, make it MRI compatible and improve the durability of the therapy.

\section{Financial Disclaimers/Conflict of Interest statement: No} commercial party having a direct financial interest in the results of the research supporting this article has or will confer a benefit upon the authors or upon any organization with which the authors are associated.

Dr. Cristiano Gomes is a Proctor for Medtronic.

Participação dos autores. Concepção e desenho: Gomes CM, Trigo-Rocha FE; Análise dos dados: Gomes CM, Henriques JCT, Costa RM; Interpretacao dos dados: Gomes CM, Henriques JVT, Costa RM; Preparo do draft do artigo: Gomes CM, Trigo-Rocha FE, Henriques JVT, Costa RM; Revisão crítica do conteúdo intelectual: Gomes CM, Trigo-Rocha FE; Aprovaçao final da versão a ser publicada: Gomes CM, Trigo-Rocha FE, Henriques JVT, Costa RM.

\section{REFERENCES}

1. Tanagho EA, Schmidt RA. Bladder pacemaker: scientific basis and clinical future. Urology. 1982;20(6):614-9. https:// doi.org/10.1016/0090-4295(82)90312-0.
2. Tanagho EA, Schmidt RA, Orvis BR. Neural stimulation for control of voiding dysfunction: a preliminary report in 22 patients with serious neuropathic voiding disorders. J Urol. 1989;142(2 Pt 1):340-5. https://doi.org/10.1016/S00225347(17)38751-7.

3. Schmidt RA, Bruschini H, Tanagho EA. Feasibility of inducing micturition through chronic stimulation of sacral roots. Urology. 1978;12(4):471-7.

4. Laviana A, Jellison F, Kim JH. Sacral neuromodulation for refractory overactive bladder, interstitial cystitis, and painful bladder syndrome. Neurosurg Clin N Am. 2014;25(1):33-46. doi: 10.1016/j.nec.2013.08.001.

5. Powell CR, Kreder KJ. Long-term outcomes of urgencyfrequency syndrome due to painful bladder syndrome treated with sacral neuromodulation and analysis of failures. J Urol. 2010;183(1):173-6. doi: 10.1016/j.juro.2009.08.142.

6. Chiarioni G, Palsson OS, Asteria CR, Whitehead WE. Neuromodulation for fecal incontinence: an effective surgical intervention. World J Gastroenterol. 2013;19(41):7048-54. doi: 10.3748/wjg.v19.i41.7048.

7. Rosen A, Taragano L, Condrea A, Sidi A, Ron Y, Ginath S. Effects of sacral neuromodulation on urinary and fecal incontinence. Isr Med Assoc J. 2015;17(6):351-5. Available from https://www.ima.org.il/FilesUpload/IMAJ/0/152/76420. pdf.

8. Abrams P, Cardozo L, Fall M, et al. The Standardisation of Terminology of Lower Urinary Tract Function: Report from the Standardisation Sub-committee of the International Continence Society. Neurourol Urodyn 21: 167-178, 2002. https://doi.org/10.1016/S0090-4295(02)02243-4.

9. Gormley EA, Lightner DJ, Faraday M, Vasavada SP. Diagnosis and treatment of overactive bladder (nonneurogenic) in adults: AUA/SUFU guideline amendment. J Urol. 2015;193(5):1572-80. doi: 10.1016/j.juro.2012.09.079.

10. Yoshimura N, de Groat WC. Neural control of the lower urinary tract. Int J Urol. 1997;4(2):111-25. https://doi. org/10.1111/j.1442-2042.1997.tb00156.x.

11. Leng WW, Chancellor MB. How sacral nerve stimulation neuromodulation works. Urol Clin North Am. 2005;32(1):118. doi: 10.1016/j.ucl.2004.09.004.

12. Malaguti S, Spinelli M, Giardiello G, Lazzeri M, Van Den Hombergh U. Neurophysiological evidence may predict the outcome of sacral neuromodulation. J Urol. 2003;170(6 Pt 1):2323-6. doi: 10.1097/01.ju.0000095921.81600.4d.

13. Marcelissen TA, Leong RK, de Bie RA, van Kerrebroeck PE, de Wachter SG. Long-term results of sacral neuromodulation with the tined lead procedure. J Urol. 2010;184(5):1997-2000. doi: $10.1016 /$ j.juro.2010.06.142

14. Spinelli M, Sievert KD. Latest technologic and surgical developments in using InterStim Therapy for sacral neuromodulation: impact on treatment success and safety. Eur Urol. 2008;54(6):1287-96. doi: 10.1016/j. eururo.2008.01.076.

15. Siegel S, Noblett K, Mangel J, Griebling TL, Sutherland SE, Bird ET, et al. Three-year Follow-up Results of a Prospective, Multicenter Study in Overactive Bladder Subjects Treated With Sacral Neuromodulation. Urology. 2016; 94:57-63. doi: 10.1016/j.urology.2016.04.024.

16. Leong RK, De Wachter SG, Nieman FH, de Bie RA, van 
Kerrebroeck PE. PNE versus 1st stage tined lead procedure: a direct comparison to select the most sensitive test method to identify patients suitable for sacral neuromodulation therapy. Neurourol Urodyn. 2011;30(7):1249-52. doi: 10.1002/ nau.20979.

17. Amend B, Khalil M, Kessler TM, Sievert KD. How does sacral modulation work best? Placement and programming techniques to maximize efficacy. Curr Urol Rep. 2011;12(5):327-35. doi: 10.1007/s11934-011-0204-2.

18. Siegel S, Noblett K, Mangel J, Griebling TL, Sutherland SE, Bird ET, et al. Results of a prospective, randomized, multicenter study evaluating sacral neuromodulation with InterStim therapy compared to standard medical therapy at 6-months in subjects with mild symptoms of overactive bladder. Neurourol Urodyn. 2015;34(3):224-30. doi: 10.1002/ nau. 22544.

19. Schmidt RA, Jonas U, Oleson KA, Janknegt RA, Hassouna MM, Siegel SW, et al. Sacral nerve stimulation for treatment of refractory urinary urge incontinence. Sacral Nerve Stimulation Study Group. J Urol. 1999;162(2):352-7. https:// doi.org/10.1016/S0022-5347(05)68558-8.

20. Hassouna MM, Siegel SW, Nyeholt AA, Elhilali MM, van Kerrebroeck PE, Das AK, et al. Sacral neuromodulation in the treatment of urgency-frequency symptoms: a multicenter study on efficacy and safety. J Urol. 2000;163(6):1849-54. https://doi.org/10.1016/S0022-5347(05)67558-1.

21. Herbison GP, Arnold EP. Sacral neuromodulation with implanted devices for urinary storage and voiding dysfunction in adults. Cochrane Database Syst Rev. 2009(2):CD004202. doi: 10.1002/14651858.CD004202.pub2.

22. Noblett K, Siegel S, Mangel J, Griebling TL, Sutherland SE, Bird ET, et al. Results of a prospective, multicenter study evaluating quality of life, safety, and efficacy of sacral neuromodulation at twelve months in subjects with symptoms of overactive bladder. Neurourol Urodyn. 2016;35(2):246-51. doi: 10.1002/nau.22707.

23. Amundsen CL, Richter HE, Menefee S, Komesu YM, Arya LA, Gregory WT, et al. Sacral Neuromodulation versus OnabotulinumtoxinA for Refractory Overactive Bladder. J Urol. 2016;195(4S):e949. Available from: https://www. jurology.com/article/S0022-5347(16)03668-5/pdf.

24. Smits MA, Oerlemans D, Marcelissen TA, Van Kerrebroeck PE, De Wachter SG. Sacral neuromodulation in patients with idiopathic overactive bladder after initial botulinum toxin therapy. J Urol. 2013;190(6):2148-52. doi: 10.1016/j. juro.2013.07.017.

25. Groen J, Blok BF, Bosch JL. Sacral neuromodulation as treatment for refractory idiopathic urge urinary incontinence: 5 -year results of a longitudinal study in 60 women. J Urol. 2011;186(3):954-9. doi: 10.1016/j.juro.2011.04.059.

26. Peeters K, Sahai A, De Ridder D, Van Der Aa F. Long-term follow-up of sacral neuromodulation for lower urinary tract dysfunction. BJU Int. 2014;113(5):789-94. doi: 10.1111/ bju. 12571 .

27. Leong RK, Marcelissen TA, Nieman FH, De Bie RA, Van Kerrebroeck PE, De Wachter SG. Satisfaction and patient experience with sacral neuromodulation: results of a single center sample survey. J Urol. 2011;185(2):588-92. doi: 10.1016/j.juro.2010.09.090.

28. Davis T, Makovey I, Guralnick ML, O'Connor RC. Sacral neuromodulation outcomes for the treatment of refractory idiopathic detrusor overactivity stratified by indication: lack of anticholinergic efficacy versus intolerability. Can Urol Assoc J. 2013;7(5-6):176-8. doi: 10.5489/cuaj.11251.

29. Yazdany T, Bhatia N, Nguyen J. Determining outcomes, adverse events, and predictors of success after sacral neuromodulation for lower urinary disorders in women. Int Urogynecol J. 2011;22(12):1549-54. doi: 10.1007/s00192011-1512-2.

30. Levin PJ, Wu JM, Siddiqui NY, Amundsen CL. Does obesity impact the success of an InterStim test phase for the treatment of refractory urge urinary incontinence in female patients? Female Pelvic Med Reconstr Surg. 2012;18(4):243-6. doi: 10.1097/SPV.0b013e31826150fe.

31. Peters KM, Killinger KA, Gilleran J, Boura JA. Does patient age impact outcomes of neuromodulation? Neurourol Urodyn. 2013;32(1):30-6. doi: 10.1002/nau.22268.

32. Peters KM, Killinger KA, Gilleran JP, Bartley J, Wolfert C, Boura JA. Predictors of reoperation after sacral neuromodulation: a single institution evaluation of over 400 patients. Neurourol Urodyn. 2017;36(2):354-9. doi: 10.1002/ nau. 22929.

33. Angioli R, Montera R, Plotti F, Aloisi A, Montone E, Zullo MA. Success rates, quality of life, and feasibility of sacral nerve stimulation in elderly patients: 1-year follow-up. Int Urogynecol J. 2013;24(5):789-94. doi: 10.1007/s00192-0121928-3.

34. Groenendijk PM, Lycklama a Nyeholt AA, Heesakkers JP, van Kerrebroeck PE, Hassouna MM, Gajewski JB, et al. Urodynamic evaluation of sacral neuromodulation for urge urinary incontinence. BJU Int. 2008;101(3):325-9. doi: 10.1111/j.1464-410X.2007.07258.x

35. South MM, Romero AA, Jamison MG, Webster GD, Amundsen CL. Detrusor overactivity does not predict outcome of sacral neuromodulation test stimulation. Int Urogynecol J Pelvic Floor Dysfunct. 2007;18(12):1395-8. doi: 10.1007/s00192-007-0351-7

36. Drossaerts J, Rademakers K, van Koeveringe G, Van Kerrebroeck P. The value of urodynamic tools to guide patient selection in sacral neuromodulation. World J Urol. 2015;33(11):1889-95. doi: 10.1007/s00345-015-1479-6.

37. Alsyouf M, Keheila M, Marinone M, Blackburn A, Staack A. Magnetic resonance imaging of the ankle performed on an InterStim patient. Can J Urol. 2016;23(1):8168-70.

38. Chermansky CJ, Krlin RM, Holley TD, Woo HH, Winters JC. Magnetic resonance imaging following $\operatorname{InterStim}(\mathrm{R})$ : an institutional experience with imaging safety and patient satisfaction. Neurourol Urodyn. 2011;30(8):1486-8. doi: 10.1002/nau.21147.

39. MRI Guidelines for InterStim Therapy neurostimulation systems 2012. Available from: http://manuals.medtronic. com/wcm/groups/mdtcom_sg/@emanuals/@era/@neuro/ documents/documents/contrib_214172.pdf.

40. Wang Y, Hassouna MM. Electrical stimulation has no adverse effect on pregnant rats and fetuses. J Urol. 1999;162(5):17857. https://doi.org/10.1016/S0022-5347(05)68238-9.

Submitted for publication: March 30, 2018

Accepted in: June 25, 2018 